\title{
O LUGAR DE FALA: apresentação do dossiê
}

\section{THE PLACE OF SPEECH: dossier presentation}

\author{
Giovanni Boaes *
}

\section{Resumo}

O artigo apresenta os textos que compõem o dossiê temático Poéticas políticas afrodiaspóricas: abordagens interdisciplinares. Para isso, dialoga com o conceito "lugar de fala", por meio do qual se dirige a outros conceitos que compõem o repertório conceitual das "peças" do dossiê, como poéticas políticas, pensamento pós-colonial, violência epistêmica, negritude, subalternidade, entre outros.

Palavras-chave: Lugar de Fala, Poéticas Políticas Afrodiaspóricas, Negritude, Arte.

\begin{abstract}
The article presents the texts that make up the thematic dossier Afrodiasporic political poetics: interdisciplinary approaches. For this, it dialogues with the concept "place of speech", through which it addresses other concepts that make up the conceptual repertoire of the "parts" of the dossier, such as political poetics, postcolonial thinking, epistemic violence, blackness, subalternity, among others.
\end{abstract}

Keywords: The Place of Speech, Afrodiasporic Political Poetics, Blackness, Art.

[...] os acontecimentos da ordem do encontro são como encruzilhadas poéticas, e para entender essa perspectiva é necessário abrir mais um caminho que atribua importância a um pensamento de vertente afro-brasileira, entendendo por extensão o "lugar de fala" de um sujeito como um depoimento do seu corpo-testemunha.

(SOARES, 2018, p. 32)

Como disse no editorial, coube a mim a tarefa de apresentar um dossiê que não organizei, embora, no processo, o editor acabe se tornando coorganizador. Se faço a apresentação, é movido por um profundo senso de obrigação, pois continuo achando que, se feita pelo organizador, sairia muito mais apropriada. Porém não pagarei a ausência com desculpas, a não ser aquelas que dirijo às autoras e autores dos textos, pois certamente sentiriam suas falas mais bem localizadas em uma "encruzilhada" textual sinalizada pelo professor Stênio Soares, com quem têm algum tipo de vínculo: na cor da pele, na prática

\footnotetext{
* Doutor em Sociologia pela UNESP/Brasil. Professor titular do Departamento de Ciências Sociais da Universidade Federal da Paraíba/Brasil. E-mail: giboaes@gmail.com.
} 
artística, nas negras memórias, na pesquisa, nos palcos, enfim, no corpo-testemunha, nos acontecimentos da ordem do encontro, no lugar de fala.

Quando comecei a ler os textos do dossiê, senti-me invadido por um tempo no qual não estive presente. $\mathrm{O}$ tempo em que Abdias do Nascimento lutava para criar uma linguagem estética, intelectual, militante e sensível que mostrasse à sociedade a face do negro. Uma face que não mais precisasse se pintar com pó de arroz para se passar por branco. ${ }^{1}$ Um rosto negro que poderia se pintar de todas as cores no palco, mas sem ocultar a sua cor de base: histórica, injustiçada, silenciada, porém teatral, vociferante. Era o tempo inicial do Teatro Experimental do Negro.

Da mesma forma, chegaram de supetão várias ideias e trechos de falas deslocadas e turbilhonantes, saídas das páginas de livros lidos durante minha incursão pelos terrenos das religiões afro-brasileiras. Autores e autoras associados aos embates a favor ou contrários às "políticas identitárias" como reivindicações e lutas concretas de minorias.

Esses momentos de reflexão me levam a encarar um conceito central em tudo isso. Trata-se do "lugar de fala", que neste dossiê não se presta a ser apenas um conceito, mas, acima de tudo, uma tradução/encarnação na forma de contranarrativas ou contrassentenças, como diria Spivak (2010). É um termo que ganhou vida em outros lugares, "escapulindo da academia", e, para o bem ou para o mal, tem gerado polêmicas e confrontos intelectuais e militantes. Como registra Djamila Ribeiro (2017, p. 31), "sobre [esse] conceito pairam muitas dúvidas."

O que é esse "lugar de fala", do qual tanto se tem falado?

Gayatri Chakravorty Spivak, cujo nome dispensa apresentações, pelo menos nos contextos de imersão pós-colonial ou decolonial, publicou um texto que se tornou referência para os termos do debate. Mas não é o único. Nessa seara, há outros nomes importantes, principalmente relacionados ao feminismo negro, a exemplo de Grada Kilomba, Patricia Hill Collins e Linda Alcoff, entre outras (RIBEIRO, 2017, p. 31), sem mencionar as intelectuais negras brasileiras, como a própria Djamila Ribeiro.

\footnotetext{
${ }^{1}$ Refiro-me ao caso do jogador negro de futebol do Fluminense, Carlos Alberto que, em 1914, teve que se cobrir com pó de arroz para poder participar de uma partida contra o América. Naquele tempo, o futebol era muito mais atravessado por uma linha de cor: aos negros, reservavam-se as funções de bastidores e logística; aos brancos, o palco principal.
} 
O texto de Spivak, no original, Can the Subaltern Speak?, foi publicado em 1985, e traduzido para o português com o título: Pode o subalterno falar? Kilomba (2019) registra algo pertinente que, em si, já diz muito sobre o lugar de fala. Trata-se da tradução do título, pois se o termo inglês subaltern não tem gênero, e ao ser traduzido para o português adotou o gênero masculino, tem-se aí, a meu ver, uma redução do lugar de fala da autora: “[...] mulher, teórica, filósofa e crítica de gênero da Índia que tem feito uma das contribuições mais importantes para o pensamento global, revolucionado os movimentos feministas com a sua escrita" (KILOMBA, 2019, p. 20-21). Aqui, ao contrário do que se pode pensar, não há dissonância, senão uma afirmação do conceito, pois as escolhas dos tradutores refletem as posições que ocupam em uma sociedade "colonialista e patriarcal" - usando-se as expressões da própria Spivak. Na tradução, "não são somente corpos de sentido que são transferidos, mas também as opções de linguagem que emanam das inúmeras escolhas que se colocam ao agente da tradução" (ALMEIDA, 2010, p. 17).

Can the Subaltern Speak? tem o objetivo de criticar os esforços atuais do Ocidente para problematizar o sujeito, destacando "como o sujeito do Terceiro Mundo é representado no discurso ocidental" (SPIVAK, 2010, p. 20). Para isso, a autora faz uma leitura crítica do pensamento de Foucault e Deleuze — intelectuais que estão "falando a partir do Primeiro Mundo, sob a padronização e regulamentação do capital socializado, embora não pareçam reconhecer isso" (SPIVAK, 2010, p. 54) —, mostrando que, apesar da denúncia que fazem sobre a violência epistêmica, eles constroem suas ideias sem romper com essa mesma violência epistêmica, o que lhes leva a perpetuar a representação dos subaltern sempre como objeto, nunca como sujeito. Duas das mais expressivas falhas das suas ideias são a ausência de uma teoria da ideologia e a apresentação dos subaltern como uma categoria monolítica e indiferenciada.

Por outro lado, a autora coloca em xeque algumas ideias e procedimentos do próprio grupo ao qual se considera ligada: Grupo de Estudos Subalternos.

À pergunta: Can the subaltern speak?, Spivak responde negativamente. A questão, em si, traz derivações: se os subaltern não podem falar, poderiam eles, especialmente as subalternas, representarem a si mesmos? Se a resposta também é negativa, quem poderia representá-los? O/as intelectuais branco/as? A autora, então, traz 
para a argumentação dois sentidos para o termo "representação", de acordo com seu significado na língua alemã: vertretung e darstellung. $\mathrm{O}$ primeiro se refere à representação do "falar por" (como ocorre na política); o segundo refere-se ao "representar" (como aparece na arte e na filosofia). No jogo dialético entre esses significados, ela situa sua argumentação crítica que nos leva ao "lugar de fala" e à impossibilidade de os subaltern falarem ou de serem representados, especialmente pelo Sujeito ocidental. Segundo ela, a prática radical deve estar atenta a esse duplo sentido do termo "representação" (SPIVAK, 2010, 43).

Sensível à situação das mulheres, a partir da sentença de que os subaltern não são uma categoria homogênea, reconhece que "se no contexto da produção colonial, o sujeito subalterno não tem história e não pode falar, o sujeito subalterno feminino está ainda mais profundamente na obscuridade" (SPIVAK, 2010, p. 67). Para explorar essa sentença, a autora analisa o sacrifício das viúvas (sati). As mulheres subalternas, (todas as indianas, incluindo as viúvas) nunca deram seu testemunho (a voz-consciência) sobre a sentença apresentada pelos homens brancos europeus (criminalização e abolição do sati) ou pelos homens de pele escura — os indianos — (exaltação da boa viúva, pois era sua vontade se sacrificar), no sentido de que a sentença elaborada pelos primeiros representava casos de "homens brancos salvando mulheres de pele escura de homens de pele escura", e para os segundos, a reafirmação da nulidade da mulher frente aos homens. As mulheres de pele escura não falavam, e se falassem, ninguém as escutaria por força de uma violência epistêmica. Mas o testemunho delas traria elementos para a constituição de uma contrassentença frente às sentenças dos homens brancos e dos homens de pele escura.

Spivak, ao dizer que os subaltern não podem falar, não está reduzindo-os a uma nulidade enunciativa e política, e menos ainda, subjetiva ou da "micrologia"; eles/as podem falar, porém, suas vozes não atingirão as frequências necessárias para reverberarem na "macrologia". Não se trata de uma sentença universalista e essencialista, trata-se de considerar que em situações de violência epistêmica, os subaltern não podem falar, pois o desenvolvimento deles/as (de consciência, representação e verbalização) é complicado pelos diversos tipos de "colonização". Ela nos lembra que a violência epistêmica "é um projeto orquestrado, vasto e heterogêneo de se construir o sujeito colonial como o Outro" (SPIVAK, 2010, p. 47). 
Em suma, "lugar de fala" não se dirige às experiências individuais necessariamente, mas às condições sociais "marcadas" de determinados grupos, permitindo-lhes ou não que acessem lugares de cidadania, que tenham ou não determinadas oportunidades (RIBEIRO, 2017). Mas o termo não é simplesmente um glosador, e, talvez, por isso tenha gerado tantas confusões e polêmicas. Sobressai o seu valor crítico e militante:

O falar não se restringe ao ato de emitir palavras, mas de poder existir. Pensamos lugar de fala como refutar a historiografia tradicional e a hierarquização de saberes consequente da hierarquia social.

Quando falamos de direito à existência digna, à voz, estamos falando de locus social, de como esse lugar imposto dificulta a possibilidade de transcendência. Absolutamente não tem a ver com uma visão essencialista de que somente o negro pode falar sobre racismo, por exemplo (RIBEIRO, 2017, p. 36).

Um episódio que se associa ao atual contexto de mudanças e enfrentamentos, e que se torna um bom exemplo para reflexões e ajustes de teorias e ideologias a partir do "lugar de fala", foi o caso da professora Lilia Schwarcz. Divulga-se apressadamente que a eminente professora e pesquisadora da USP, cuja carreira acadêmica está dedicada a estudar as relações raciais e a combater o racismo, foi acusada por intelectuais e influenciadores negros de ser aquilo que combate: racista. Pelo pouco que sei sobre o caso ("um exame interessado e imperito"), não me parece ser essa a questão que se gerou a partir dos comentários feitos pela professora (SCHWARCZ, 2020) sobre o filme Black is King, protagonizado por Beyoncé. O que se coloca é até que ponto uma intelectual branca — racista ou não, "falando sob a padronização e regulamentação do capital socializado"2 — tem o direito de "re-presentatividade" sobre as vivências negras. O que mais pesa na acusação, segundo alguns de seus críticos, é o ar de soberba que impregna o texto de Lilia Schwarcz.

Era de se esperar que tal acontecimento gerasse reação da intelectualidade, afinal, a voz do "outro" é como uma navalha "cega" que começa a tirar, a contrapelo, pedaços da pele que reveste a branquitude, incomodando a/os que dela se revestem. Um exemplo desse incômodo, dentre outras questões, pode ser lido no texto de Almudras (2021), o

\footnotetext{
${ }^{2}$ Expressão usada por Spivak (2010, p. 54) para se referir a Foucault e Deleuze.
} 
qual me eximirei de comentar aqui, deixando que os leitores/as tirem suas próprias conclusões. ${ }^{3}$

Para falar, é preciso usar um código, e esse código, em um regime de dominação epistêmica, carrega a dominação em cada símbolo, signo e regra gramatical. Portanto em uma empreitada de descolonização, é preciso que se crie um código subalterno (o "Pretuguês", por exemplo) ${ }^{4}$ dentro do código hegemônico, com seu vocabulário e articulações próprias, que como uma bomba possa implodi-lo gradativamente. Grada Kilomba, na apresentação que fez especialmente para a edição em português do seu Memórias da plantação: episódios de racismo cotidiano (KILOMBA, 2019), destaca o quanto o idioma português carrega muito fortemente as marcas de um passado colonial e patriarcal.

Permitam-me refletir sobre isso usando um fato "editorial". Ao revisar os textos que compõem este dossiê, percebi que alguns autores escreviam palavras, consideradas substantivos comuns, com letras maiúsculas (negros, africanos etc.), o que, pelo código hegemônico, caracterizar-se-ia como erro gramatical. Pensei que se tratava de um ato de insurgência contra a violência epistêmica manifestada na língua, e me vi no dilema: corrigir ou não. Porém, para se insurgir contra algo, não é suficiente fazê-lo no silêncio, é necessário que o silêncio seja quebrado, e se diga, se fale abertamente sobre o que se pretende fazer, e os motivos da ação. Assim evita-se a possibilidade de que um propósito seja tomado como um mero erro gramatical. Como editor e revisor, fiz os ajustes de acordo com o padrão hegemônico. Mandei as versões corrigidas aos autores e autoras para as validarem. Não houve reclamações, contrariando minhas expectativas. Também não averiguei o motivo do silêncio e aquiescência. O simples tamanho de uma letra cria efeitos de sentido importantes para uma causa. Como diz Kilomba (2019, p. 14), “a língua [...] tem também uma dimensão política de criar, fixar e perpetuar relações de poder e de violência, pois cada palavra que usamos define o lugar de uma identidade".

Escrever substantivos comuns com letras maiúsculas seria — ainda que modestamente - advogar uma propriedade, a identidade de sujeito que a história negou

\footnotetext{
${ }^{3} \mathrm{O}$ texto foi escrito sob pseudônimo. Segundo o autor, "o motivo disso está evidente. Nestes tempos de cruzadas autoritárias moralistas e de narcisismo midiático neoliberal, uma crítica como a que fiz aqui tem de lançar mão da privacidade autoral como escudo e refúgio" (ALMUDRAS, 2021, online).

${ }^{4}$ Sobre o "Pretuguês", ver Ribeiro (2017, p. 17).
} 
àqueles/as a quem as palavras grafadas com letras minúsculas se referem. $\mathrm{O}$ contrário também traz um efeito de sentido, ou seja, bell hooks tem um propósito interessante ao exigir que o seu nome, que pelas convenções linguísticas deveria ser grafado com letras maiúsculas, seja grafado com letras minúsculas. E assim, podemos dizer que a língua pode também servir de instrumento para descriar, desfixar e interromper relações de poder e violência, pelo mesmo motivo alegado por Kilomba: o uso que se pode fazer de cada palavra define o lugar de uma identidade - e eu acrescentaria: de "poder, desejos, interesses" $"$, de propósitos. Poderíamos ir mais longe e perguntar, a qual identidade estamos nos referindo? E o que é um identidade? Não que isso seja pouco importante, mas creio que trilhar esse caminho nos levaria muito além dos objetivos desta apresentação.

O que são poéticas políticas afrodiaspóricas? Como essa noção anima os textos produzidos para este dossiê?

Elas são - como diz Stênio Soares (2020, p. 13) — expressões poéticas que se mostram como

\begin{abstract}
formas de resistência do artista negro e se instauram como depoimentos, no sentido de apresentar elementos, argumentos ou indícios de uma experiência. Ao depor sobre o fenômeno vivido, a linguagem se manifesta como um testemunho do próprio artista negro como um sujeito social, e sua linguagem é um comprometimento do seu corpo. Por isso, entendemos que essas criações se apresentam como depoimentos do corpo-testemunha, e, portanto, elas são formas de conhecimento e formas de empoderamento dos artistas negros, que comprometem e empregam, a partir do seu próprio corpo, as impressões coletivas sob um ponto de vista da experiência vivida por si.
\end{abstract}

Elas fazem parte de uma gramática e de um código que se projetam contra a violência epistêmica. Enfatizando o que disse acima o organizador deste dossiê, o corpotestemunha é também um corpo protagonista, um corpo que se revolta e que fala sobre a revolta, ao mesmo tempo, por meio da arte como representação em seu duplo sentido (vertretung e darstellung). Parafraseando Kilomba (2019, p. 28), este dossiê "representa

\footnotetext{
${ }^{5}$ Coloquei essas palavras entre aspas para fazer alusão à importância que lhes é dada por Spivak em Can the Subaltern Speak?, fórmula em três etapas com a qual a autora inicia o texto. Elas estarão no centro da crítica que fará a Foucault e Deleuze.
} 
esse desejo duplo: o de se opor àquele lugar de 'Outridade' e o de inventar a nós mesmos de (modo) novo".

Poéticas políticas afrodiaspóricas são contranarrativas ou contrassentenças, como diria Spivak, que se opõem à violência epistêmica. Acho que os autores, autoras e o organizador concordariam com Ribeiro $(2017$, p. 11) de que os textos por eles e elas produzidos — intelectuais-artistas-negros e negras — procuram mostrar "a importância de [pautarem] como sujeitos as questões que são essenciais para o rompimento da narrativa dominante e não [serem] tão somente capítulos em compêndios que ainda pensam a questão racial como recorte."

Daí, depreende-se a importância deste dossiê, cujos autores e autoras e seus textos passarei a apresentar brevemente.

Comecemos pelo organizador. Stênio Soares é professor e pesquisador do Departamento de Técnicas do Espetáculo da Escola de Teatro da Universidade Federal da Bahia (UFBA) e do Programa de Pós-Graduação em Estudos Étnicos e Africanos (PósAfro/CEAO/UFBA) e Mestrado Profissional em Artes (Prof-Artes/UFBA). Doutorou-se em Artes em 2018, fez o mestrado em Estética e História da Arte, ambos pela Universidade de São Paulo (USP). Iniciou sua carreira acadêmica na Universidade Federal da Paraíba no Curso de Ciências Sociais. Durante a graduação, fez estágios na Faculdade de Antropologia e Sociologia da Université Lumière Lyon 2 na França.

Iniciou sua carreira de artista e performer ainda na graduação, momento em que também foi se gestando o seu interesse pelas questões da negritude em perspectiva crítica. Saindo de João Pessoa, desvia-se das ciências sociais e ingressa no campo acadêmico das artes. Foi aluno da Licenciatura em Teatro da Universidade Federal da Bahia (UFBA), fez especialização em museologia, e o mestrado, seguido do doutorado, na mesma área, ou seja, artes.

O seu interesse de estudo e pesquisa se volta para temas interdisciplinares no campo das culturas afro-brasileiras, tratando da diversidade religiosa, das corporeidades afro-brasileiras nos jogos e nas danças populares; e da pesquisa estética e histórica relacionadas às matrizes afrodiaspóricas. A sua tese de doutoramento - $O$ corpotestemunha na encruzilhada poética - procura, em um diálogo muito vivo com as ciências sociais, com o feminismo negro e os estudos pós-coloniais produzir um aparato 
conceitual adequado para se compreender as vivências negras em contextos afrodiaspóricos. "A ideia de corpo-testemunha surgiu durante o desenvolvimento do processo poético intitulado Negras Memórias" (SOARES, 2020, p. 15). No processo de criação artística, o autor elaborou um conceito que inspira alguns textos deste dossiê.

O corpo-testemunha, como já disse linhas acima, para o autor, representa expressões poéticas como formas de resistência. Um conceito que surgiu a partir da reflexão que empreendeu sobre outro conceito já discutido aqui: lugar de fala. Diz o autor:

\begin{abstract}
Embora as ideias que cerquem o conceito de lugar de fala tenham sido aprimorados dentro do debate promovido pelo feminismo negro, hoje, elas se estendem para outros contextos, por vezes completamente diferentes e que pode, em essência, divergir dos princípios que lhe foram basilares. E foi com essa preocupação, respeitando a historicidade do conceito de lugar de fala, que ao lidar com minha linguagem poética e com a linguagem poética de outros artistas, acreditei que o conceito de corpo-testemunha contemplasse melhor o que gostaria de argumentar, reconhecendo, entretanto, a historicidade conceitual que ele carrega (SOARES, 2020, p. 18).
\end{abstract}

Lamento a ausência do organizador — que se deu por razões justificáveis. Seu texto, certamente, exploraria mais as ideias sobre o corpo-testemunha, poéticas políticas afrodiaspóricas, encruzilhadas, entre outros. Para compensar essa perda, indico link para palestra, na qual ele apresenta a sua tese sobre o corpo-testemunha. ${ }^{6}$

Vamos, então, à apresentação dos textos e seus autores e autoras. Seguirei a ordem traçada pelo organizador.

Janaína Machado, bacharela em linguística pela Universidade de São Paulo, atualmente fazendo o mestrado em Estudos Étnicos e Africanos na Universidade Federal da Bahia, atuando junto ao Núcleo de Mediação da Fundação Bienal de São Paulo, escreve o primeiro artigo: "Não somos fãs de canalha": poéticas políticas afrodiaspóricas na $34^{a}$ Bienal de São Paulo.

A autora reflete sobre a produção artística do elenco de artistas negros e negras selecionados para a mostra Vento da $34^{\mathrm{a}}$ Bienal de São Paulo, iniciada em 2020. Toma como material de reflexão as obras de Paulo Nazareth, Musa Michelle Mattiuzzi, Neo Muyanga \& Coletivo em Legítima Defesa e Deana Lawson, tendo como chave de leitura as poéticas do corpo-testemunha de Stênio Soares, poética da relação de Édouard Glissant,

\footnotetext{
${ }^{6} \mathrm{https}: / /$ www.youtube.com/watch?v=bPsNANBvWwo.
} 
autodeterminação e autorrevelação de Audre Lorde, poéticas políticas de Achille Mbembe e "radiografia" dos Racionais MC'S. O texto é enriquecido com ilustrações visuais das obras analisadas, e direciona-nos a perceber que a produção artística dos artistas negros e negras ganham contornos estéticos como resposta à sua condição política e racial no mundo, "relação que se expressa de forma relacional e não unilateral, ou seja, são poéticas que convocam leituras das relações sociais que são estruturalmente racializadas."

Monica Pereira de Santana escreve o segundo artigo: Mulheres negras, performance negra e reinvenções: reflexões sobre a performance negra e as mulheres negras como artistas e intelectuais. Ela se define como artista do corpo e da palavra. Possui uma trajetória profissional multidisciplinar que se iniciou com o bacharelado em Comunicação Social (Jornalismo) e culminou com o mestrado e doutoramento, em andamento, em Artes Cênicas pelo Programa de Pós-Graduação em Artes Cênicas da Universidade Federal da Bahia. Atualmente, tem se dedicado a construir uma cartografia de criadoras negras contemporâneas.

O artigo, que é parte da pesquisa que a autora está realizando para o doutoramento, discute a forma como as produções artísticas e de conhecimento de mulheres negras foram pilhadas historicamente, excluindo-as das noções tradicionais de autoria. Ao analisar o conceito de performance negra, apresenta-o como um espaço de produção de sentido e, ao mesmo tempo, como lugar de produção de si e de existência.

A linha de interpretação adotada pela autora persegue a "hipótese de que há, pela primeira vez nas artes cênicas brasileiras, a condição de fala de mulheres negras, desenvolvendo projetos autorais, friccionando as narrativas impostas ao longo do processo histórico e a semântica justaposta aos seus corpos.” A partir dessa indicação, algumas performances negras aparecem como material de análise: Isto não é uma mulata (da própria autora), Merci beaucoup, banco! (de Michelle Mattiuzzi), Tutorial (de Yasmin Nogueira) e Black off (de Ntando Cele). Texto e fotografias se combinam para anunciar que as produções artísticas autorais das mulheres negras, apesar da pilhagem histórica, conclamam por mudanças, por novas formas de agir e existir.

O terceiro artigo - Afrocentricidade na obra teatral "Dona Maria do Doce": ensino de arte e perspectivas antirracistas — foi escrito por Fernanda Mara Ferreira Santos, em 
coautoria com Victor Hugo Neves de Oliveira (orientador), a partir do seu trabalho de conclusão do curso de Licenciatura em Teatro da UFPB, apresentado em 2020.

Fernanda é atriz, arte-educadora, contadora de histórias, artivista e pesquisadora das temáticas referentes à educação, arte e relações étnico-raciais. Além da Licenciatura em Teatro, possui especialização em Arte-Educação e Uso de Novas Tecnologias pela Universidade de Brasília, especialização em Literatura e Culturas Africanas e Afro-brasileiras pela Universidade Estadual da Paraíba. Atualmente, é professora de Artes na Socioeducação, e desenvolve trabalhos artísticos e socioculturais de valorização da estética negra/preta no estado da Paraíba.

Victor Hugo é artista e pesquisador em dança. Professor do Departamento de Artes Cênicas da Universidade Federal da Paraíba e do Mestrado Profissional em Artes (PROFArtes/UFPB). Desenvolve pesquisas sobre a educação das relações étnico-raciais no contexto das Artes da Cena.

No artigo, a autora coloca em análise, a partir de perspectiva afrocentrada, a obra teatral "Dona Maria do Doce". Um conto para ser performado nos processos de arte-educação contra a hegemonia da branquitude e o racismo. É uma produção autoral desenvolvida no seio do Coletivo Gira Contos Contadores de Histórias, que tem como contadora de históriaperformer, a própria autora. Para ela, a arte de contar histórias foi uma ponte com o fazer artístico ancestral, há muito distorcido e deslocado pela violência epistêmica. Vê nessa tarefa — contar histórias, arte-educar - uma oportunidade de empoderamento da negritude, no seu caso, uma negritude "sexuada", ou seja, da mulher negra. Um dos pontos forte do texto é a apresentação, sem medo, que a autora faz sobre o que entende ser uma perspectiva afrocêntrica, e como ela pode ser localizada e vivida na realidade.

O quarto artigo foi escrito por Heverton Luís Barros Reis. Ator e mestrando em Estudos Étnicos e Africanos pela Universidade Federal da Bahia, além de ser bacharel em Artes pela UFBA, licenciado em História pela Universidade do Estado da Bahia e especialista em Metodologia do Ensino de Artes.

Em O teatro afrodiaspórico e ritualístico do Núcleo Afro-brasileiro de Teatro de Alagoinhas (NATA), Heverton procura "refletir sobre as contribuições do teatro negro brasileiro no embate ao racismo, exclusão social, intolerância religiosa e da luta por visibilidade". Volta-se para o NATA com o intuito de refletir sobre os sentidos de teatro 
negro. O fazer teatral do Núcleo é polivalente: ritualístico, engajado, afrocentrado e multilíngue. $\mathrm{O}$ autor parte para explorar as características acima mencionadas, especialmente o caráter ritualístico, ao colocar em análise o espetáculo Exu: a boca do universo, concebido pelo NATA em 2014: "o primeiro espetáculo a refletir a cultura negra em diálogo com o candomblé, apoiado pelo programa de manutenção artística do Teatro Castro Alves”. A inspiração para o espetáculo veio da importante figura de Onisajé, yakekerê de candomblé e encenadora/dramaturga, cujos endereçamentos se dirigem para pensar os corpos negros (dentro e fora dos palcos) a partir da relação entre arte e política. Heverton arremata o artigo com a afirmação de que o teatro negro é plural, pois precisa abraçar as múltiplas identidades dos negros; são teatros de conflitos e lutas por definição. Poética e esteticamente, são "teatrosquilombo urbanos: do interior para o exterior", dos quais o NATA é um bom exemplo.

José Joaquim de Araújo Filho escreve o quinto artigo. Museólogo, ator e doutorando no Programa Multidisciplinar de Pós-Graduação em Estudos Étnicos e Africanos (Pós-Afro) da Universidade Federal da Bahia. Também é mestre em Museologia e tem duas graduações: Museologia e Artes Plásticas, ambas pela UFBA. É professor e pesquisador no campo museológico, patrimonial, comunicações etnográficas e comunicação museológica, com ênfase em culturas e memórias africanas e afrodiaspóricas. Por conta de suas pesquisas, esteve no Senegal, Gana, Togo, Benin Etiópia, Quênia, Tanzânia, África do Sul e Mali.

O seu artigo - O negro nas arenas de representações: um paralelo entre o teatro e a museologia numa perspectiva afrocentrada - reflete, a partir de perspectiva afrocentrada, sobre as similitudes e diferenças entre o teatro e a museologia como disciplinas acadêmicas. Começa examinando as origens do teatro e do museu para compreender como eles se estruturaram historicamente. Em seguida, volta-se para a situação dos negros nessas duas arenas representacionais. Para exemplificar os tensionamentos envolvidos no processo de representação, analisa a exposição temporária Exu: outras faces, exibida no Museu AfroBrasileiro da Universidade Federal da Bahia, e a peça teatral Pele negra, máscaras brancas, encenada pela Cia de Teatro da Universidade Federal da Bahia.

A análise da exposição revela que o museu teve o papel de contranarrativa ao mostrar a face de Exu, uma divindade advinda de outro registro religioso, que foi lida pela lente católica e social hegemônica como o Diabo cristão. José Joaquim reforça a importância do 
museu na descolonização cultural e religiosa e no combate à intolerância que se atinge diariamente as religiões de matriz africana.

Com a análise da peça teatral, cujo foco recai sobre os aspectos psicológico e filosófico dos povos negros, e que traz o mesmo título do livro de Frantz Fanon, obra que a inspira, José Joaquim mostra como o teatro negro tem o papel de veicular dispositivos antirracistas, e gerar empoderamento para os negros. Nas suas palavras de arremate: "O teatro e o museu, como arenas de poder, são peças-chave nesses processos [de representações empoderadas dos sujeitos negros] em que narrativas e discursos são (re)construídos".

Jéssica Sampaio da Silva escreve o sexto artigo: Entre afetos: reflexões a partir de uma experiência de aquilombamento teatral universitário. Ela é graduada em Gestão Ambiental pelo Centro Universitário Jorge Amado, licenciada em Teatro pela UFBA. Atriz, pesquisadora e agitadora cultural dos coletivos teatrais "E" ao Quadrado e Fraude Pura. O texto que nos apresenta é derivado do seu trabalho de conclusão de curso (Licenciatura em Teatro), e foi orientado por Stênio Soares.

A partir da noção de aquilombamento teatral universitário, inspirada nas ideias de Abdias de Nascimento sobre o quilombismo, a autora reflete sobre o processo de investigação/criação do espetáculo Interiores do Coletivo Teatral Fraude Pura, do qual é integrante. O que Interiores nos diz sobre poéticas políticas afrodiaspóricas? Como um trem — diz a autora - "o espetáculo transita entre a memória dos atores, revelando as relações com a geografia e as saudades". Nos seus vagões, traz a ancestralidade e conhecimentos para confrontá-los com a realidade urbana. Não se resume a um espetáculo teatral, é um laboratório afrocentrado, ou seja, engajado na atuação política e estética a partir do lugar de fala da negritude. O texto encontra-se muito próximo a um relato de experiência, focando-se nas vivências da autora dentro do Coletivo. Sabe, porém, articular o diálogo entre as suas subjetividades e as subjetividades do grupo, mostrando como as duas realidades são atravessadas pelas mesmas forças que condicionam o lugar de fala dos artistas negros/as universitários/as. Os encontros que o espetáculo Interiores proporciona, nas palavras da autora, "é um recorte para compreender o impacto da presença de artistas negros [e negras] no contexto da formação artística universitária".

O sétimo artigo — Dança e política na encruzilhada floresta-favela — foi escrito a quatro mãos. Hugo César da Silva Ledo é ator e graduado em Letras pela Universidade de 
São Paulo. Angelita Alves Gonçalves é mestranda em Educação e licenciada em Pedagogia, ambos pela Universidade de São Paulo. Também é licenciada em Técnica em Artes Cênicas pelo Instituto Paula Souza.

A partir do espetáculo de dança Para que o céu não caia, da Cia Lia Rodrigues de danças, companhia que atua no Complexo de Favelas da Maré, no Rio de Janeiro desde 2003, os autores analisam a linguagem da dança como um fenômeno social, procurando compreender os processos que se desenvolvem na articulação da criação artística com o cotidiano de vulnerabilidade dos povos das florestas e dos moradores das "favelas". Os autores nos mostram que a Cia Lia Rodrigues, por meio de seus espetáculos, cria "manifestações políticas dançantes". E a "dança cênica Para que o céu não caia tem como desenvolvimento e ressonância a necessidade de comunicar, fazer ecoar o que precisa ser ouvido e levado a sério para cessar a barbárie, o genocídio e a intensificadora relação degradante com a natureza antes que seja tarde demais”. O grande esforço dos autores é compreender as aproximações entre arte e política, especialmente por meio da dança engajada, denunciadora e resistente. Terminam o texto com certo tom de pessimismo, pois percebem que a obra de arte está atualizada, mas a realidade não mudou. $\mathrm{O}$ recado que a criação artística veicula continua emudecido diante do poder opressor.

Fechando o dossiê, Larissa Ferreira nos apresenta o ensaio visual Aiyê: dançar a vida em corpo búzio de carne. São dez imagens que representam cenas do espetáculo Aiyê, resultado de projeto de pesquisa em dança criado pela autora; mais do que um ensaio, é como diz ela — "um manifesto visual", pois traz, por meio da performance de mulheres negras, "a beleza de um legado ancestral" e a denúncia contra as atrocidades do racismo estrutural.

Aiyê é uma palavra yorubá que significa terra. Opõe-se e complementa-se a/em outra palavra: Orun, que significa a morada dos orixás. Elas enredam os mitos de alguns povos africanos que vieram para o Brasil na situação de escravizados. Aiyê e Orun, conta o mito, já estiveram ligados diretamente, e humanos e orixás conviviam pacificamente no mesmo lugar. Porém, com medo de que a humanidade poluísse o branco das vestes dos orixás funfum, pelo golpe do opaxorô, Aiyê e Orun se separaram. Mas os orixás sentiram falta daquela convivência, por isso, Oxum, uma poderosa orixá, encarregou-se de providenciar um canal através do qual os deuses pudessem visitar a humanidade. A religação (religare) passa a 
ocorrer por meio da incorporação, ou seja, o corpo dos/as humanos/as se tornou a morada dos deuses. É no corpo que Aiyê e Orun se encontram, e a energia que move o encontro é a dança.

O que junta orixás e humanos/as é a mesma energia que se pode notar no "manifesto visual" que Larissa e suas dançarinas-pesquisadoras nos apresentam. A beleza e a grandeza do simbolismo da ancestralidade africana e da afro-brasileira (presente na cosmogonia dos orixás) são representadas nos corpos das artistas negras que dançam o Aiyê como um verdadeiro transe de religação.

Larissa Ferreira é artista, capoeirista, pesquisadora e docente na Licenciatura em Dança do Instituto Federal de Brasília. Doutora e mestra em Artes pela Universidade de Brasília, licenciada em Dança pela Universidade Federal da Bahia, e coordena o Grupo de Pesquisa Corpografias.

Editar e apresentar este dossiê me afetou significativamente. Não vou dizer que acho simples desembarcar em todas as estações aonde o "lugar de fala" pode nos levar, e confesso que uso com muita reserva e reflexão crítica o repertório tecido no seio dessa epistemologia, como "protagonismo", "sabedoria marginal", "empoderamento", "resistência", "politicamente correto" e o próprio "lugar de fala". Porém tudo isso me leva a refletir sobre mim mesmo. Afinal, qual pele me reveste? Meus desejos, interesses e projetos navegam em qual rio? Quantas foram as encruzilhadas que atravessaram meu caminho, e eu não as percebi?

Cheguei à conclusão de que, na minha vida, acadêmica ou não, quase sempre me deixei impregnar pelo "ar de soberba" — a exemplo de Lilia Schwarcz e Almudras —, traço típico da intelectualidade forjada em uma epistemologia colonizada/racializada, e afirmei facilmente, com palavras, gestos e omissões, que a "zebra é um animal branco com riscos pretos". 7

Embora não me considere branco, sou um corpo-testemunha que se passa por branco. Para mim, então, o principal efeito do envolvimento com este dossiê foi perceber que brancos precisam pensar sobre a "não marcação" da branquitude (KILOMBA, 2019, p. 62), ou seja,

\footnotetext{
${ }^{7}$ Refiro-me a uma alegoria criada por João Milando, utilizada por Mata (2014 ) para iniciar seu texto sobre o pensamento pós-colonial.
} 
perceber que branquitude também é objeto, é recorte, e que negritude também é sujeito. As coisas parecem se encaminhar para uma situação na qual os meios-termos se esmaecem. Mas em um país costurado com este tipo de agulha (mito da mestiçagem/brasilidade) e de linha (mito da democracia racial), nosso "repertório de disposições" tende a resistir e a persistir no terreno da violência epistêmica contra os subaltern.

Mas elas e eles estão falando. Finalizo esta apresentação, convidando os leitores e leitoras a escutá-las/os.

\section{Referências}

ALMEIDA, Sandra R. G. Prefácio: apresentando Spivak. In: SPIVAK, Gayatri Chakravorty. Pode o subalterno falar? Belo Horizonte: Editora da UFMG, 2010, p. 7-17.

ALMUDRAS, Benamê Kamu. Parece revolução, mas é só neoliberalismo. Revista Piauí/Folha UOL, n. 172, jan. 2021 (Online). Disponível em: https://piaui.folha.uol.com.br/materia/parecerevolucao-mas-e-so-neoliberalismo/. Acesso em: 02 maio 2021.

KILOMBA, Grada. Memórias da plantação: episódios de racismo cotidiano. Rio de Janeiro: Cobogó, 2019.

MATA, Inocência. Estudos pós-coloniais: desconstruindo genealogias eurocêntricas. Civitas, Porto Alegre, v. 14, n. 1, p. 27-42, 2014. Disponível em: https://doi.org/10.15448/19847289.2014.1.16185. Acesso em: 15 mar. 2021.

RIBEIRO, Djamila. O que é lugar de fala? Belo Horizonte: Letramento; Justificando, 2017. (Coleção Femininos Plurais).

SCHWARCZ, Lilia Moritz. Filme de Beyoncé erra ao glamorizar negritude com estampa de oncinha. Folha de São Paulo. (Online), 2 ago. 2020. Disponível em: https://www1.folha.uol.com.br/ilustrada/2020/08/filme-de-beyonce-erra-ao-glamorizar-negritudecom-estampa-de-oncinha.shtml. Acesso em: 15 maio 2021.

SOARES, Stênio José Paulino. As poéticas da negritude e as encruzilhadas identitárias: uma abordagem a partir da noção de corpo-testemunha. Rascunhos, Uberlândia, v. 1, n. 7, p. 10-29, 2020. Disponível em: http://www.seer.ufu.br/index.php/rascunhos/article/view/55518/29276. Acesso em: 30 maio 2021.

SOARES, Stênio José Paulino. O corpo-testemunha na encruzilhada poética. 2018. Tese (Doutorado em Artes Cênicas) - Universidade de São Paulo, São Paulo, 2018. Disponível em: https://www.teses.usp.br/teses/disponiveis/27/27155/tde-20072018-111159/pt-br.php. Acesso em: 20 maio 2015.

SPIVAK, Gayatri Chakravorty. Pode o subalterno falar? Belo Horizonte: Editora da UFMG, 2010.

Recebido em: 29/05/2021.

Aceito em: 03/06/2021. 